\title{
Principles of all-inclusive public health: developing a public health leadership curriculum
}

Citation for published version (APA):

Smith, T., Stankunas, M., Czabanowska, K., de Jong, N., O'Connor, S., \& Fowler Davis, S. (2015).

Principles of all-inclusive public health: developing a public health leadership curriculum. Public Health, 129(2), 182-184. https://doi.org/10.1016/j.puhe.2014.12.001

Document status and date:

Published: 01/01/2015

DOI:

10.1016/j.puhe.2014.12.001

Document Version:

Publisher's PDF, also known as Version of record

Document license:

Taverne

Please check the document version of this publication:

- A submitted manuscript is the version of the article upon submission and before peer-review. There can be important differences between the submitted version and the official published version of record.

People interested in the research are advised to contact the author for the final version of the publication, or visit the DOI to the publisher's website.

- The final author version and the galley proof are versions of the publication after peer review.

- The final published version features the final layout of the paper including the volume, issue and page numbers.

Link to publication

\footnotetext{
General rights rights.

- You may freely distribute the URL identifying the publication in the public portal. please follow below link for the End User Agreement:

www.umlib.nl/taverne-license

Take down policy

If you believe that this document breaches copyright please contact us at:

repository@maastrichtuniversity.nl

providing details and we will investigate your claim.
}

Copyright and moral rights for the publications made accessible in the public portal are retained by the authors and/or other copyright owners and it is a condition of accessing publications that users recognise and abide by the legal requirements associated with these

- Users may download and print one copy of any publication from the public portal for the purpose of private study or research.

- You may not further distribute the material or use it for any profit-making activity or commercial gain

If the publication is distributed under the terms of Article $25 \mathrm{fa}$ of the Dutch Copyright Act, indicated by the "Taverne" license above, 


\title{
Short Communication
}

\section{Principles of all-inclusive public health: developing a public health leadership curriculum}

\author{
T. Smith ${ }^{a, *}$, M. Stankunas ${ }^{b}$, K. Czabanowska ${ }^{c}$, N. de Jong ${ }^{d}$, S. O'Connor ${ }^{e}$, \\ S. Fowler Davis ${ }^{f}$
}

a Sheffield Hallam University, Centre for Leadership in Health and Social Care, Faculty of Health and Wellbeing, United Kingdom

${ }^{\mathrm{b}}$ Lithuanian University of Health Sciences, Kaunas, Lithuania

${ }^{\mathrm{c}}$ Maastricht University, Department of International Health, Faculty of Health, Medicine and Life Sciences, The Netherlands

${ }^{\mathrm{d}}$ Maastricht University, Department of Health Services Research, CAPHRI School for Public Health and Primary Care, Faculty of Health, Medicine and Life Sciences, The Netherlands

e Canterbury Christ Church University, Department of Nursing and Applied Clinical Studies and The England Centre for Practice Development, United Kingdom

${ }_{\mathrm{f}}^{\mathrm{f}}$ Centre for Health and Social Care Research, Sheffield Hallam University, 32 Collegiate Crescent Sheffield, S10 2BP, United Kingdom

\section{A R T I C L E I N F O}

Article history:

Received 30 May 2013

Received in revised form

12 November 2014

Accepted 1 December 2014

Available online 21 February 2015

Public health challenges and the nature of ill health are evolving. Modern societies are afflicted with a broad range of health problems, ${ }^{1}$ including epidemics of over consumption, ${ }^{2}$ rising rates of mental distress and disorder, ${ }^{3}$ diminishing levels of well-being and increasing health and social inequalities. ${ }^{4}$ To add further complexity the social and economic drivers of these problems, such as globalisation, an aging workforce, ${ }^{5}$ consumerism, individualism and economism, are increasingly considered as barriers to sustainable health improvement because they rely on unsustainable exploitation of finite natural resources. ${ }^{1}$ Finally, due to the impact of global recession, European health systems are under increasing financial pressure to deliver more with diminishing resources.

This perfect storm of health challenges requires a multidisciplinary public health workforce, who possess new skills and expertise. ${ }^{6}$ Today's public health practitioner needs to be able to work constructively in a turbulent environment, with a wider range of stakeholders than ever before. In order to develop effective public health interventions, they have to be able to build strong collaborative networks and teams at every level of the public health system, from politicians and policy makers to the mass media and the public. The skills required to affect constructive change in these complex health care settings, and work across disciplines effectively, are not the traditional technical and academic skills that public health is founded upon, but are those of effective leadership. ${ }^{7}$

Organisations and professionals worry about the capacity of future public health leaders. ${ }^{7}$ Policy makers are concerned about the future responsiveness of the discipline and the presence of competent leaders is regarded as crucial to achieve progress in the field ${ }^{7}$ and solve complex public health challenges. $^{8}$

\footnotetext{
* Corresponding author. Centre for Leadership in Health and Social Care, Sheffield Hallam University, Parkholme, 30 Collegiate Campus, Sheffield S10 2BP, United Kingdom. Tel.: +44 114225 5878; fax: +44 1142252394.

E-mail address: t.smith@shu.ac.uk (T. Smith). 
Improving leadership capacity amongst public health professionals raises several challenges including; the identification of key leadership competencies, the most effective ways of teaching leadership and an adequately tailored public health leadership curriculum to address the needs of European public health professionals. An international group of educators and public health professionals have collaborated to address the above needs by developing a syllabus for a European Public Health Leadership course. The project was guided by the following objectives, to:

- Examine the key debates around leadership in public health in relationship to political, economic, social and, technological change and their implications for leaders within organisations;

- Introduce key theoretical frameworks that underpin leadership learning, and enable the critical use of this knowledge and understanding by applying theory to actual practice within the context of public health;

- Develop the ability to reflect on the Public Health Leadership role and development needs of individuals; and

- Stimulate self-assessment of leadership competencies by public health professionals.

The Leaders for European Public Health project (LEPHIE) was devised as a transfer of innovation from the DELTAH project; an action research programme that developed, piloted and evaluated evidence based European Healthcare Leadership programmes. DELTAH, which was funded by the EC Leonardo da Vinci Lifelong Learning programme between 2004 and 2007, provided the starting point for the LEPHIE project to develop an evidence based European Public Health Leadership programme (Table 1).

Using systematic search and analysis methods to review available literature, a framework of eleven themes were identified. The themes were: Political Leadership, Ethical

Table 1 - A comparison of the LEPHIE literature review results and the DELTAH Curriculum.

\begin{tabular}{ll}
$\begin{array}{l}\text { LEPHIE literature review } \\
\text { results }\end{array}$ & \multicolumn{1}{c}{$\begin{array}{c}\text { DELTAH leadership } \\
\text { programme curriculum }\end{array}$} \\
\hline $\begin{array}{l}\text { Transformational leadership } \\
\text { Transactional leadership }\end{array}$ & $\begin{array}{l}\text { Introduction to leadership } \\
\text { (transformational, transactional } \\
\text { and laissez Faire leadership } \\
\text { impact) }\end{array}$ \\
Strategic leadership and & $\begin{array}{l}\text { Systems thinking (problem } \\
\text { definition and analysis }\end{array}$ \\
systems thinking & Self leadership \\
Collaborative leadership & Team, intergroup and partnership \\
& working \\
Team leadership & Presentation skills \\
Communication & Leadership, conflict and \\
& negotiation \\
Leading change
\end{tabular}

Leadership, Strategic Leadership and Systems Thinking, Charismatic/Transformational Leadership, Change Emotional Intelligence, Team Leadership, Collaborative Leadership, Communication and Transactional Leadership. These both reinforced and contrasted with the previous project (DELTAH). Transformational and Transactional leadership, Systems thinking and strategy, Emotional Intelligence, Collaboration and Partnership working, Communication and Negotiation featured in both projects. Political Leadership, Ethical Leadership, and Change Leadership were overtly identified in the literature analysis, but did not appear in the DELTAH themes perhaps reflecting the differing use of terminology and possibly concurring with the term, 'effective leadership'.

A Masters Level module of eight credits under the European Credit Transfer System (ECTS) (equivalent to 15 UK level seven credits) was designed. Care was taken to ensure the that the course was tailored specifically to the context of European public health, with each session developed around specific problems that reflect EU public Health priorities; in particular chronic disease and ageing. The initial curriculum was developed, piloted and evaluated at Sheffield Hallam University in the UK and after an external, independent evaluation; a revised curriculum was piloted at Maastricht University, Netherlands, Kaunas University, Lithuania and University of Graz, Austria. To increase relevance and learning effectiveness the final curriculum consists of eight sessions, which integrate public health and leadership content. ${ }^{9}$ They are delivered by different university centres either face-to-face or on-line. Each session includes interactive lectures, problem scenarios. There are also a series of recorded interviews available with public health leaders from a variety of European Countries.

LEPHIE identified relatively few prior studies to support curriculum development for public health leaders in Europe. The literature review and resulting framework minimizes the gap in knowledge and helps to promote an awareness of the need to define a set of competencies and assessments to suit the learning needs of public health leaders in a broad area of practice. The UK public health register ${ }^{10}$ (for example) covers a wide range of roles, from those who operate at strategically at policy or a health systems level, to those concerned with the practicalities of delivering public health interventions but makes no mention of leadership requirements. The authors would argue that leadership competencies are relevant across virtually all public health roles. They do however need to be applied appropriately according to the particular role and context public health practitioners find themselves in. For example, whilst health promotion practitioners are not politicians, they may find themselves in intensely political situations where a clear sense of vision, political engagement, advocacy and local policy development are required. Similarly, public health professionals in the most senior strategic roles are also part of teams, need to collaborate, and have excellent communication skills to be fully effective.

The literature analysis and framework development confirmed and extended previous consensus based methods of curriculum design in Public Health Leadership.

In conclusion, the LEPHIE European Public Health leadership curriculum aims to fill an important gap in public health education. A European Public Health leadership programme, run by a collaborative of European Higher Education 
institutions through the auspices of The Association of the Schools of Public Health in European Region (ASPHER) is a key development to support the public health workforce. Further work to ensure the sustainable delivery through higher education institutions across Europe is ongoing and delivery is continually supported in its original form, or adapted for specific public health contexts or roles.

\section{Author statements}

\section{Acknowledgements}

All authors have made substantial contributions to all of the following: (1) the conception and design of the study, or acquisition of data, or analysis and interpretation of data; (2) drafting the article or revising it critically for important intellectual content; and (3) final approval of the version to be submitted.

\section{Ethical approval}

Not required.

\section{Funding}

This study was supported by the European Commission Lifelong Learning Program in the framework of ERASMUS Multilateral Curriculum Development project: Leaders for European Public Health (LEPHIE). Project $n^{\circ}$ 510176-LLP-1-2010-1-NLERASMUS-ECDCE.

\section{Competing interests}

None declared.

\section{R E F E R E N C E S}

1. Hanlon P, Carlisle S, Hannah M, Lyon A. The future public health. Maidenhead: Open University Press; 2012.

2. Department of Innovation Universities and Skills. Foresight tackling obesities: future choices 2007; October 2007. DIUS/PUB/ $2 \mathrm{~K} / 10 / 07 / \mathrm{NP}$.

3. World Health Organisation. Prevention of mental disorders: effective interventions and policy options: summary report; 2004. ISBN $924159215 \mathrm{X}$.

4. CSDH. Closing the gap in a generation: health equity through action on the social determinants of health. Final report of the commission on social determinants of health; 2010.

5. Hawley SR, Romain TS, Orr SA, Molgaard CA, Kabler BS. Competency-based impact of a state-wide public health leadership training program. Health Promot Pract 2011;12(2):202-8.

6. World Health Organisation. Strengthening public health capacities and services in Europe: a framework for action. Regional Committee for Europe 61st session. Baku, Azerbaijan:12-5. EUR/RC61/10. 2011; Available at:, http://www.euro.who.int/ en/; September 2011 [accessed 08 September 2012].

7. Koh HK, Jacobson M. Fostering public health leadership. J Public Health 2009;31(2):199-201.

8. Hunter DJ. Leading for health and wellbeing: the need for a new paradigm. J Public Health 2009;31(2):202-4.

9. Czabanowska K, Smith T, editors. Leadership for public health in Europe - student module book. Maastricht University; 2013. Available from: http://www.lephie.eu/lephie_repository.html. 10. UKPHR Public Health Register. Introduction to the UK public health register route to registration for public health practitioners; 2011. 